\title{
About/Of Madness: Ann Quin's The Unmapped Country
}

The British avant-garde writer Ann Quin (1936-1973) is experiencing something of a renaissance. However, The Unmapped Country (1973), Quin's final, unfinished book, and my focus here, has not (until now) been widely available, and so has not yet been part of this discussion. ${ }^{1}$ This article argues that Unmapped is a key text in Quin's oeuvre. While Berg (1964), Three (1966), Passages (1969) and Tripticks (1972) are all differently concerned with heightened, fragmented, multiple, elusive, allusive and chaotic psychiatric states, Unmapped explicitly deals with the state of - and therefore with the possibility of the representation of - madness. In her lifetime, Quin's work was criticised for the increasingly radical nature of its experimentation and escalating intertextuality, while this last text was praised for its seeming return to a more familiar form. In fact, as my reading demonstrates, the text continues and extends Quin's earlier interrogation and troubling of questions of narrative representation.

In 1972-1973, Quin was studying at Hillcroft Women's College, an environment and occupation which provided respite from increasingly severe mental breakdowns and periods of psychosis. There, in February 1973, she wrote an essay on George Eliot's Middlemarch and suffragism; at the same time, she re-read Eliot's Daniel Deronda and was working on Unmapped. The title of Unmapped is taken from a moment in Daniel Deronda where the question of the elusive, unknowable nature of the psyche is raised as well as how it might be possible to represent, narrate, or know this, alerts us to the fact that Quin's text has similar concerns. $^{2}$ I begin by considering that Daniel Deronda passage, in order to draw out the 
ambivalence of its narration and troubling of the language of reason before discussing how such questions play out in Quin's brilliantly unsettling text. Although the And Other Stories version of Unmapped brings together previously separate fragments of the text, this article primarily focusses on the first chapter, which narrates Sandra's experience in a psychiatric hospital. This is because my particular concern here is with Quin's representation of the institutionalisation of madness, the way madness eludes the language of reason, and questions of narrative perspective. Nevertheless, the shifting and unstable narrative

perspective of the second chapter, which narrates Sandra's experiences of visions prior to incarceration, will inform and enhance the discussion.

\section{A great deal of unmapped country within}

But that movement of mind which led her to keep the necklace, to fold it up in the handkerchief, and rise to put it in her nécessaire, where she had first placed it when it had been returned to her, was more peculiar, and what would be called less reasonable. It came from that streak of superstition in her which attached itself both to her confidence and her terror - a superstition which lingers in an intense personality even in spite of theory and science; any dread or hope for self being stronger than all reasons for or against it. Why she should suddenly determine not to part with the necklace was not much clearer to her than why she should sometimes have been frightened to find herself in fields alone: she had a confused state of emotion about Deronda - was it wounded pride and resentment, or a certain awe and exceptional trust? It was something vague and yet mastering, which impelled her to take this action about the 
necklace. There is a great deal of unmapped country within us which would have to be taken into account in an explanation of our gusts and storms. ${ }^{3}$

Gwendolen Harleth (Eliot's difficult and complex female protagonist) feels compelled to keep 'the necklace' she had previously attempted to pawn, a necklace she rightly suspects Daniel Deronda (the titular character) of recovering on her behalf. When Gwendolen is impelled by 'something vague and yet mastering' not to try to rid herself of the necklace a second time, Eliot's third-person narrator seems to know what makes her act in this way - 'it came from that streak of superstition in her' - whereas Gwendolen herself does not. In the passage, as elsewhere in the novel, Gwendolen's confusion about Deronda is used to suggest a larger uncertainty and unknowability within Gwendolen herself. This 'unmapped country' within her, the text suggests, can in turn tell us about an unknown within people in the world outside the text, something 'within [all of] us' that 'would have to be taken into account in an explanation of our gusts and storms'. In this characteristic move from particular character to universal experience, Eliot's narrator seems simultaneously situated within and outside of the world of the text, able to speak to and of both. It is this kind of authoritative position that Colin MacCabe interprets as Eliot's metanarrative - 'that language which tells us what is really happening. ${ }^{4}$

However, here as elsewhere in her writing, Eliot's narrator is not the transparent and unwritten window on reality MacCabe claims it to be. Gwendolen's 'movement of mind', the narrator tells us, is 'more peculiar, and what would be called less reasonable'. This 'what would be called' troubles the narrator's position. It 'would be called less reasonable', but by whom? The narrator does not claim such a judgment for themselves, and there is the suggestion that what is 'reasonable' 
may not always offer an adequate articulation of 'peculiar' experience. Neither the language of reason, nor the narrator, can quite pin down 'that movement of mind', can quite explain or articulate it. As with the unknowability of the 'unmapped' country, this moment in the passage demonstrates a troubling of the authority of the narrator as much as an enactment of it - we see the window as much as looking through it - and the ambivalence of the reading and writing process is called to our attention. Gwendolen recognises the rescuings of the necklace as portents, signifiers of things to come if only she were able to read them correctly, and while in some ways the narrator can read, understand and articulate things Gwendolen herself cannot, its position is nevertheless also partial and limited. In this way, the passage foregrounds the difficulty of attempting to represent the human psyche.

This brief discussion of Daniel Deronda is offered as a way in to thinking about Unmapped, to draw out how Eliot's writing might have been particularly suggestive for Quin's attempt to represent 'madness'. ${ }^{5}$ In Writing and Madness, Shoshana Felman asks whether and how it might be possible to know or write madness at all given that this will also always necessarily be in the language of 'reason, which masters and represses madness' and therefore always works to exclude and deny it. ${ }^{6}$ A similar focus on the potential failure or limitations of the language of reason is, I suggest, present in Eliot's thinking about the limits of narration, in the suggestion that Gwendolen's 'movement of mind ... was more peculiar, and what would be called less reasonable'- here the 'reasonable' prose of the third-person narrator can only gesture towards but not fully explain or know the psyche. If we follow Felman, and accept that peculiar or 'unreasonable' experience refuses meaningful articulation, Eliot's claim that the unmapped must be taken into account in an explanation of 'our gusts and storms' can be taken further to ask how 
or whether a text might explain, know or express madness (the 'unmapped', unknown or even unknowable) at all.

This article reads Unmapped as enacting a kind of response to such questions. With Felman's thinking as my primary critical frame, I argue that Quin is similarly engaged in probing the possibility of writing madness. My method closely attends to the detail of Unmapped in order to draw out and demonstrate how the overemphatic, clichéd and reiterative language and formal mechanisms reject and ironise the approach of reason or explanation. In conclusion, I propose that Quin's writing works to activate (rather than describe) madness at the level of the text itself: the question is not only what madness might mean, but what it does.

\section{About Madness}

'Good morning and how are we today?'

'Bloody rotten if you must know.'

'Why is that - tell me more?'

Silence. Patient confronted psychiatrist. Woman and man. She looked at the thin hair he had carefully placed over his yellow husk. Thin lips, almost no lips. Thick hands, bunches of spiders on his knuckles. He wrote or doodled, leaning forward, back.

'I don't like your madness.'

'What do you mean by that, Sandra?' 
Pen poised, ready to stab yet another record. She could not see his eyes, the light bounced, spiralled in his spectacles. Black tentacles crept from his nostrils. In the distance a woman screamed. (159)

The first chapter of Unmapped narrates its protagonist Sandra's experience of madness and incarceration in a psychiatric hospital: in this, the chapter raises the question of the possibility of writing about madness; particularly within in an institutional context. It opens with the lines above, a description of Sandra's morning session with one of the hospital psychiatrists. This is written from a predominantly third-person perspective which closely sympathises with the protagonist. The patient psychiatrist opposition is not only stated-'[p]atient confronted psychiatrist' - it is also exacerbated by the dehumanising, revolting description of the almost lipless, yellow husked, pen stabbing and eyeless doctor. This description is in staccato, reduced to fragments of close-up detail: the result is both observationally specific and evocative but also sent up, villain-esque. The strangeness of the details - the 'bunches of spiders on his knuckles,' the 'black tentacles' which creep from his nostrils - undermines the sense in which the clarity of the prose could imply an objective or 'transparent' record of the meeting. The nature of the description and effect of the exaggeration calls into question whose perspective the narrative is focalised from; whether Sandra's or the narrator's. Here as across Unmapped, Quin employs an ambivalent and destabilising free indirect style. What results is an exaggerated, ambiguous description, one which knows that the notion of the 'evil' doctor and mad 'victim' are already encoded and mapped out. Thus the passage plays out stereotypical power oppositions-sane/mad, doctor/patient, man/woman, human/animal, villain/victim—while at the same time subverting and undoing them: the patronising 'how are we today' is cut down by the 'bloody rotten' answer. In this, the writing 
does not so much describe the scene as it performs and interrogates already overly encoded and stereotyped ideas.

Sandra, under attack from the doctor's questioning, offers mutinous silence and terse, tightly controlled answers in return, despite the horror of having to listen to another woman screaming. In contrast with this inarticulate and agonised sound heard 'in the distance,' Sandra's protests are perfectly comprehensible and lucid; they are also ludic, irreverent and playful: she says it is the doctor's madness she does not like. Significantly, his response is to ask what she means, which admits that her speech could indeed have meaning, in spite of her supposed 'madness.' This question is central to my reading of Quin here: in what ways it might be possible for language and writing to mean madness? Sandra's lucid-ludic response is a detail which indicates the wider double-sense of Quin's writing in this text, as well as elsewhere in her writing, where what seems to be in one register often carries within it and implies the sense of another. This works to produce a narrative perspective that continually undermines and unravels itself: the possibility of writing meaningfully 'about' Sandra's madness, from the outside, is challenged at the very same time as being performed.

The first chapter charts the course of one of Sandra's days and is in short sections that communicate its scheduled minutiae. Sandra converses with psychiatrists and fellow patients, writes in and reads old entries in her diary, and attends a group therapy session and ward party; she spends time walking and drawing shapes in snow in the hospital grounds, as well as several times trying (and not being allowed) to go to sleep; she is also visited by her lover Clive, a man who wants to leave as soon as he has arrived, but not before she has performed her 'duty' and taken 'him in her mouth' 
(173). At the end of the day, and the chapter, she is finally allowed sleep. Throughout, the institutional aspect of Sandra's context is reinforced by the presence of the third-person voice, which, despite its closeness to and sometimes blurring with Sandra's perspective, is nevertheless one that primarily attempts to write about madness, to describe it from without. But, rather than being able to know or master such an experience, the text exposes such an attempt as an 'illusion of reason,'7

The Red Queen breathing through the tunnel. Her face at the bottom of the lavatory, grinned up. Flush her away. Sandra sat for some time in the lavatory, the only place she could be by herself and not be distracted, and go back over the journey; even so their voices interrupted 'It's all in the head you must realise that - in the head in the head inthehead inthehead inthehead...' and she saw the doctor's faceless presence behind his desk, like the painting 'Le Principe du Plaisir,' by Magritte, except the figure in the painting was infinitely better, more pleasing. Then there was the Red Queen's face; even when dead her mother, no doubt, would be watching her. And Clive - what of Clive? Frightened of his own madness; seeing her actions, reactions as interpretation of what he considered a madness just round the corner for himself (163).

This description of madness is a clichéd one which places Sandra's experience in the context of Lewis Carroll's 'Red Queen' and Rene Magritte's 'Le Principe du Plaisir.' Elaine Showalter claims that for women writers representing madness: 'Alice's journey through the looking glass is a more apt analogy than Ophelia's decline. ${ }^{8}$ Given this, when Sandra sees the face of her mother, referred to throughout Unmapped as the Red Queen, grinning up from the bottom of the toilet, the 
vision knows and is determined by an intertext that is clearly evident. In addition, the faceless presence of the doctor is described in direct contrast with a Magritte painting. That painting's title, translated as 'The Pleasure Principle,' of course recalls Freud, whose psychoanalytic theories sought to map the mind, and it depicts a doctor's face obliterated by a shining light representing the 'light of reason.' This reference to Magritte's image both reiterates - 'the light bounced, spiralled in his spectacles' - and contrasts with the detail of the description and behaviour of the doctor at the beginning of the chapter, which there works to undermine his status and reasonableness. As with that example, the slippage here interrogates assumptions about clear oppositions between reason and madness, clarity and confusion, knowledge and ignorance. Such a challenge is further evident in the moments of free indirect style. While the quotation marks around the 'it's all in the head' speech of 'their voices' seem to define what is articulated against what is not, in places the narration is more ambivalent and unidentified: for example, it seems to inhabit Sandra's first-person perspective with 'And Clive - what of Clive?' collapsing third-person distance. Such ambivalence is taken further in the second chapter of the book, which is narrated in a confused prose where the differences between what happens in and outside of Sandra's head are at times almost completely elided through a slippage between first and third person pronouns - an elision reminiscent of Berg or Tripticks.

In Unmapped, the blurring and ambiguity of narrative perspective is complicated by the sense in which, even when hallucinating her mother as the Red Queen grinning up at her from the bottom of a toilet, Sandra here, as in the opening extract, seems to remain lucid and ironically aware - the Magritte painting is 'infinitely better, more pleasing' than the faceless doctor she looks at - while other patients are depicted as more stereotypically 'mad' and without such articulation and self- 
awareness. For example, Thomas believes he is 'Judas Iscariot reincarnated'; that 'God is Mrs Carr, and my young friend Bob is Jesus Christ' (161). His God, Annie Carr's, speech is profane 'you cunt you bloody fucking cunt' (162): at the lunch table she exposes herself - 'Annie Carr shouted, pushing out her left breast, dipping it in the gravy' - and then tears off her nightdress 'and on all fours gave herself to the linoleum' (165). While, absurdly, Annie's behaviour poses no challenge to Thomas' belief, showing the strength of his delusional world-view, this also serves to provide another questioning of representations and perceptions of 'madness.' Indeed, the behaviours represented in Quin's text range from unnamed characters who scream, are drugged, whimper, rant and rave, to the apparently nonplussed, one of who tries on post-lobotomy wigs: 'Well I got this lobotomy op coming up and they shave the head you see - nice isn't it - they designed it specially so it would look like my own hair' (178). The multiplicity of representation here, as well as the shifts between serious and darkly humorous tones, pick up on contradictions in the way those who are apparently mad have been perceived and represented in literature and art—from grotesquely bestial to visionary seer. ${ }^{9}$

As well as playing with stereotypes of madness, Unmapped reinforces other (then recent) literary representations of the psychiatric institution (such as, for example, Ken Kesey's One Flew Over the Cuckoo's Nest, Jennifer Dawson's The Ha-Ha and Sylvia Plath's The Bell Jar). The simultaneous horror and humour of Annie Carr's behaviour, the weirdly normalised chatter about lobotomy surgery and the backdrop of screams and gurgles do not represent the psychiatric hospital as a place of refuge from the outside world, but one where the mad person is confined, reduced, misinterpreted, and acted upon with drugs, electro convulsive therapy and surgery: the patients here are powerless and at the mercy of the institution and its systems. ${ }^{10}$ Although Quin's 
narrator is not an omniscient third-person, D. A. Miller's discussion of the wider 'institution' of the third-person narrator nevertheless seems useful for considering the representation of institutionalisation in Unmapped. Miller claims that even when third-person texts contain a censure of discipline and the institution, they in fact exercise policing powers of their own and the narrator is the key representative of textual institutionalism, and specifically the language of reason. ${ }^{11}$ In this way, even a supposedly sympathetic third-person narrator is also always an agent of an apparently rational interpretative frame. This kind of position can be seen in Daniel Deronda, for example, where the narrator questions the limits of its knowledge at the same time as ultimately claiming an understanding of Gwendolen that she does not have herself. In Quin's text, on the other hand, the ambivalence of the narrative perspective works to destabilise and question the 'institutions' both of third-person narrator and psychiatric hospital.

The narrative position of Unmapped is further complicated by the ambiguity of its representation of madness. Apparent sympathy is complicated by resentment of and resistance to Sandra's fellow patients, moments where the narrative seems to be horrified by and alienated from them:

Someone changed the television channel. Screams of protest.

'Well you weren't watching anyway just natter natter natter.'

'That's not fair we were watching.'

'No you fucking wasn't.'

'No need for that.'

Silence. A picture came on of a table laden with food.

'Looks nice doesn't it?' 
'Not poisoned like it is in here.'

They leaned forward and watched the picture intently.

They leaned back and swallowed their saliva; carried on chattering, nose picking, knitting; fingers plucked at buttons, cigarettes, fingers at fingers, a battle of insects (183).

The anonymising and distancing effects of 'someone' and 'they' here is reinforced by the disembodied and depersonalised speech of the squabbling patients. 'They' have been so reduced by the institution (which they think feeds them 'poisoned' food) that they are left with nothing to argue about and invest in but the television - the ubiquitous drug of Tripticks. The listing technique demonstrates the dehumanising effects of an institutional experience which leaves people salivating, chattering, nose picking, reduced to 'insects.' But such a description also seems to condemn them with its own disgust: their frantic, plucking fingers and the knitting are ordinary activities made strange, frightening and ridiculous. In this way, at the same time as criticising what is done to the patients, here again, as with the cliché of the Red Queen, the narrative voice remains at a distance from them. This double-effect, which both sympathises with and is removed from these patients, works to simultaneously reinforce and problematise the notion that madness can be written about. The wider cast of characters provide a familiar 'known' sense of the chaos and bedlam of archetypal mad-people, but it is precisely because of this that the narrative is unable to penetrate or know them. Here, the narrative perspective remains outside a seemingly inaccessible, unreasonable and alien experience: hence the resort to stereotype. 
In this way, Unmapped seems to show the impossibility of writing madness from without, at the same time, by showing the failure of rational language, it also questions the possibility of Sandra's experience being articulated at all:

If speech at all then it was the spaces between words, and the echoes the words left, or what might really be meant under the surface. She knew, had known. No longer knew. Only remembered. In the recollection, pictures, words, visions, thoughts, images built themselves into citadels, gigantic towers that toppled with the weight of it all; the top heavier than the foundations. Last events came first, the beginning at the end, or suddenly reversed, or slid into panels midway. Had ECT done that - damn them? (167).

For Derrida, any attempt to speak out of madness will always fail because 'madness is what by essence cannot be said. ${ }^{12}$ There is a similar absence of language here, when Sandra attempts to articulate her experience: all that remains are 'the spaces between words, and the echoes the words left. ${ }^{13}$ The passage indicates that madness has broken her relationship with language to the point that she no longer knows but only remembers what words might mean or meant, or how they might speak and relate to experience. She has lost the ability to put words in orderly - and ordinarycoherence and a space has opened up, between her experience and language, so that speech is always just out of reach. However, there is also a sense in which this particular failure of articulation - the lacunae of rational or ordinary speech — may be precisely what reaches towards 'what might really be meant under the surface.' At the same time, this possibility seems always denied and in deferral. Causality is deconstructed-'last events came first, the beginning at the end, or suddenly reversed, or slid into panels midway.' While the passage implies that this severance and obliteration may have been caused by ECT, Derrida's assertion that the attempt to 
articulate madness is always in deferral—always, we might say, an act of amnesia—would indicate that these destructive effects are the result of the illness. ${ }^{14}$ When we recall that Derrida also-in Memoirs of the Blind-likens representation itself to amnesia, writing (as representation representing) madness will always be always something doubly deferred. ${ }^{15}$

The amnesia of Sandra's relationship with language, then, engages with the vexed questions of writing (or speaking) about madness. The ambivalence of the narrative perspective, where it is not always possible to tell which words are the narrator's and which Sandra's, is particularly important here. In its attempt to articulate an unspeakable and lawless experience, Unmapped resists social regulation and standardisation, both in terms of psychiatric institutional content and narrative form The ambivalent slippage between third-person and Sandra's perspectives here works to show that attempts to articulate madness, to know or write about it in the 'language of reason' will always fail.. As Derrida points out in his critique of Foucault, and Quin's text here also demonstrates, there is the problem of how to talk about madness except in the language of reason which has exiled it: Felman puts it thus, 'to talk about madness is always, in fact, to deny it. ${ }^{16}$ In the extract above, we might read the failure as being Sandra's own, when of course, because of the filter of the language of reason, it is in fact a failure of articulation itself. Such attempts can only talk about the experience and not of it: can only ever stereotype, and therefore exclude it.

\section{Of Madness}

[T]o give madness a voice, to restore its language: a language of madness and not about it. ${ }^{17}$ 
This article argues that one of the ways Quin's writing might mean madness—give or restore it a voice-is by knowingly invoking and ironising, and therefore calling attention to and unravelling, some of its stereotypes. In this way, the focus of discussion will move away from the question of narrative perspective, to consider in more detail how repetition and cliché work to create maddened effects. A paradigmatic example of this is how the trope of 'hallucinating God' is at work in Unmapped. While R. D. Laing reinterpreted claims to seeing—or even being—God, by claiming that 'madness' (and specifically schizophrenia) might be better thought of as a mode of insight and prophecy, of religious vision and spiritual quest, the visions of God in Unmapped both invoke and unravel such a claim. ${ }^{18}$ This is clearly sent up, for example, in the behaviour of Annie Carr (in what is surely a reference to Mary Barnes, who smeared shit as self-expression during her widely publicised 'therapy' with Laing and Joseph Berke) who shouts 'May the blessed Virgin shit on you - shit shit shit' (162). ${ }^{19}$

However, the apparent critique of the romanticised stereotype of madness as spiritual quest is problematised and complicated by the insistent vision of God's face that recurs throughout Quin's writing and thinking at this time. The image is present, for example, in chapter two of Unmapped: 'Staring at the white wall I see a face appear. White against white. Soon valleys, mountains, forests, rivers, lakes and many oceans appear in the face, in the white hair and long beard. The eyes contain day and night, and in their depths stella spaces. Each strand of hair is luminous. In know it is God's face' (198). Quin's own personal experience of the vision seemed 'so much more purposeful than anything I could ever write'. ${ }^{20}$ She continues:

It's very difficult to talk about, but I just knew it couldn't be anything else. There was every possible landscape in the face: valleys, trees, mountains, hills. It was composed 
of every landscape, and it looked like a picture from Blake, with snowy white hair and a long white beard. It was important to my work because I have found it difficult to believe in writing since. ${ }^{21}$

This experience is difficult to talk about— both hard to put into words and embarrassing to admit: 'I just knew it couldn't be anything else.' This 'knowledge' is not logical or reasonable but is in fact counter to those things; nevertheless, it seems (feels) irrefutable. This is an experience on the edge of madness, for religious beliefs, experiences and visions have the strange status of being both indicators of madness and of reasonable, 'sane' faith. Like madness, a vision of God is also an experience at the very edge of what it is possible to communicate. For Quin, this crisis of knowledge and understanding is necessarily also a crisis of writing.

The slippage between Quin's vision and its ironic echoes across Unmapped is an example of reiteration at work in such a way that it begins to hiccup and unravel, to make strange and trouble meaning. The rewriting of the vision is both explicitly grounded in the romanticism of Blakewho by the 1960s had become an 'icon of campus revolution' and thus rather misread and clichéd ${ }^{22}$-at the same time as refusing it. The vision is exposed to the ridicule the writer seems to anticipate in the interview above, when Sandra attempts to capture and articulate it during a painting therapy session:

In a grain of sand the whole universe - something like that, Blake put. He had visions. A God who laughed, belched, snored and picked His nose. Her God had been straight out of Blake, long snowy beard and snowy locks, and in His face every conceivable landscape. 
'That's a funny face Sandra.'

'It's God.'

'Looks like a lump of shit to me.' A patient said, making up her face with paint brushes (172).

Here, romanticised clichés of Blake are refuted by the claim that his God was one that 'laughed, belched, snored and picked His nose' much like the patients in the television-watching extract above. The capitalised 'His' here is juxtaposed in between 'picked' and 'nose' to contradictory effect: it simultaneously both denies and bows to conventions of respect. Further, the assertion that '[h]er God had been straight out of Blake, long snowy beard and snowy locks, and in His face every conceivable landscape' is at odds with and deliberately jars with the preceding description. Moreover, when Sandra's representation of this laughing, snoring, belching, nose-picking God is likened to a 'lump of shit' not only is this comment transgressively funny, it is also a moment of verbal slippage - from face to faeces. While this faeces serves in turn to deface the face of Godjust as the patient who describes Sandra's picture 'defaces' herself with paint, which in turn again refers to Barnes' painting with shit—it also signifies an absurd ambivalence and blurred meaning, a maddened language. ${ }^{23}$ Here, not only is the repeated signifying chain of variations of the beauteous and flowing image of God disrupted by 'His' bad habits, which works to defamiliarise the repetition, but at the very level of the language itself, the face represses and denies, but also always already carries within it, the faeces. 
It is my suggestion that in such stickiness of language Unmapped slips from writing about madness to writing of it: this quality is even more evident in the effects of Quin's emphatic and excessive detail. Here, the madness is not separate to a language that speaks about it, but comes from within. In such these moments the question of perspective is undone, and language is activated into an excess it cannot know or explain. Thus, the prose seems to break free from reason's (and Sandra's) control, into 'a madness that is acted out in language, but whose role no speaking subject can assume' ${ }^{24}$

Those who were not chattering, stalked the room, or fluttered on chairs, made stabbing movements with knitting needles, skeins of coloured wool spilled onto the floor, dribbled yellow and red between flapping arms, someone croaked, another barked. A mouth opened, closed, opened again, no sound came. But eventually a howl did emerge. Doors opened, and in rushed the keepers. The howl continued. People turned their heads, froze in contorted positions, as the keepers bent over a young girl struggling on the floor; her head curiously twisted; the white of her eyes showed through dark feathers, damp with sweat. The howl changed to a gurgle, the gurgle to gasps, as the body writhed in the net of arms. And like a huge octopus the group moved slowly out of the room. The girl's shoe remained, on its side. Someone kicked it across the floor. The knitting needles pierced the air, click click click, and bodies took up their preceding positions, and went through the motions of survival of the fittest (186187).

In place of Sandra's ludic lucidity or inarticulate lacunae - the endless deferral or amnesia of speech — the sound at the centre of this passage is the howl of the young girl: this recalls the distant 
woman's scream that Sandra hears at the start of the book. Here, while initially '[a] mouth opened, closed, opened again, no sound came,' 'eventually a howl did emerge.' However, this sound of protest is soon reduced to a gurgle and then gasps as the girl is subdued by the 'keepers.' The girl is reduced to a howling beast, the image of the archetypal primordial mad person. In this, her madness both seems to reinforce the opposition of madness and reason, and, as with the characters Annie Carr and Thomas, emerges as a familiar 'role to be played. ${ }^{25}$ There is the deliberate poignancy of the abandoned shoe that is kicked across the floor: with this, the girl's victim status is confirmed. Her howl signifies her disconnection from the policing and institutional language of reason as well as her powerlessness: the doctors (or 'keepers') are the stereotyped oppressors of the piece who take her away. In turn, the howl is a sign of the condition that has led to her incarceration: a condition which is itself a label assigned from the outside and in the words of other, more 'reasonable' people for as Felman reminds us; 'the term madness is [always] borrowed from the language of others. ${ }^{26}$

Such a reading extends the discussion of Unmapped in the section above, to claim that Quin's prose exposes the inevitable failure of attempts to write about madness, because this will always work to stereotype and exclude it. However-and this is my key claim-I propose that when we look more carefully, what is also at work in the extract is precisely a language of madness. The writing is punctuated —its surface pierced — by repeating, stuttering ' $t$ 's and ' $k$ 's, which perform the violence not only of the knitting but of the illness, as well as acting to instantiate the concrete meaning of the words. These sounds repeat those in the extract cited earlier: 'chattering, nose picking, knitting; fingers plucked at buttons, cigarettes, fingers at fingers, a battle of insects' (183). The briefer evocation of the sounds there are repeated, exaggerated, and proliferated in this longer 
piece, where sustained consonance makes the language strange and unwieldy, denying transparency: this, the knotted pattern of the texture insists, is certainly not unwritten narration. Instead, the patterning of the language — a glossomania in terms of sound, movement and rhythm rather than sense-deliberately performs and instantiates the madness it writes. ${ }^{27}$ In this way the writing stutters in terms of sound patterns, but also meaning patterns, and this strains the passage to create a sense of becoming; this is description becoming something else. As Gilles Deleuze observes, stuttering often comes about as part of the attempt to capture unfamiliar or foreign experiences in such a way that language is activated into new meanings. ${ }^{28}$

But, even more than this, the performance of the language here spills over and out of control'skeins of coloured wool spilled onto the floor, dribbled yellow and red between flapping arms, someone croaked, another barked.' With this, the text unravels just as the knitting does, dramatising and infecting Quin's writing process as it juxtaposes and interweaves sound and sense connections to create a knotty and tangled surface. Knitting is knotting with gaps; it produces a tangled order out of skeins of wool. This is an ideal metaphor for writing which spills over with meaning; indeed it had already been used as such by Quin herself in Three, ${ }^{29}$ as well as by one of Quin's key influences, Virginia Woolf, in To the Lighthouse. ${ }^{30}$ Elsewhere, knotting had been used as a metaphor for the patterning of madness and psychological binds: in Knots (1970), Laing claims that language is able to reveal such experiences - ones that cannot be articulated in the language of reason - through word patterns such as 'knots, tangles, fankles, impasses, disjunctions, whirligigs, binds. ${ }^{31}$ In these examples, as well as in Unmapped here, the images of knitting and knotting both invade the text and are the text - in Quin's writing madness is generated at the point where the text, writing about itself, tangles up, knots and unravels. 
The flow of the spilling and dribbling of this undoing directly contrasts with the overwhelming quantity of jerky and unpleasant movement—stalked, fluttered, stabbing, flapping, writhed, kicked - and sound - chattering, croaked, barked, howl, click-throughout the extract. In particular, the sound of the 'click' reverberates with prose elsewhere in the chapter, for example, '[t]he nurse clicked her teeth, and took mental note of the patient's words' (164). Not only is the onomatopoeia of the 'ck' and ' $t$ ' here similarly threatening, but the repetition into a different context is strange and insistent. Such descriptions are unsettling and ambivalent. Rather than making a claim to representation, this excess creates a maddened effect: knitting has a commonsense, mundane reality in the world outside the text, but an insistent, threatening and unstable one within it. This ambivalence unsettles the reader's perception of how to receive the text-does the language or object discourse remain under the control of a third-person narrator? How does the equivocation of the words here affect meaning and interpretation? Are there places where the accelerating repetition of sounds, effects and intertexts means that the writing is no longer about madness but also somehow performs it?

It seems to me that this ambivalent effect, where the writing is both free indirect narrative description of Sandra's experience and 'writing-gone-mad'-in terms of its knitting of exaggerated signification and knotted profusion of detail-is the most persuasive way that Unmapped manages at once to be both about and of madness. This becomes clearer if we also consider the effect of the bird metaphor. The flapping, fluttering patients are as if birds in the 'parrot house' (186) with the staff as keepers. Throughout Quin's writing, birds take on an oversignified, hallucinatory quality. For example, the 'gigantic bird [which] wheeled, then plummeted 
down' (160), the gulls Sandra sees 'circle the ship's mast' (160) and the gulls that 'circled above the grey buildings' (179) in the first chapter are echoed in the ambivalent opening of the second: 'I am a bird hovering, searching for human shape' (193), which opens that part of the text with a non-human first-person perspective. These birds not only recall the gulls in Berg, but also the description of birds' flying in formation in Passages, which itself reverberates with and recalls Leonardo's description of birds' flight. ${ }^{32}$ More specifically, Sandra's distancing from language is described in terms of birds: 'Once she had understood the language of birds, now no longer, it took her all her time to understand her own language' (167). This echoes the connections made between madness and the 'language of birds' elsewhere in Quin's writing — for example, 'She had wanted to understand the language of birds. They spoke now to get out getoutgetoutget. ${ }^{33}$ In turn, these surely reference Septimus' hallucinations of birds talking to him in Greek in Woolf's Mrs Dalloway. ${ }^{34}$ In this way, Sandra's claim to have once understood the language of birds both describes an experience of madness and at the same time, through the very insistence of the imagery, activates and makes strange familiar signs of madness by sending out part-repeated ripples of already over-encoded images and ideas.

Thus, the chains of signification move across Quin's writing here and beyond to emphatically perform a sense of 'hallucinatory inflation. ${ }^{35}$ This inflation comes precisely because the images and signs in Unmapped echo and hallucinate, and are in a sense relentlessly pursued by, a literary inheritance of madness, not only of Kesey, Plath and Dawson, for example, but also Woolf, and beyond that back to Eliot's gusts and storms of the unmapped psyche. Here then, the madness of Quin's text is in part created by an obsessive internalisation and activation of others' representations of madness and mental unease. This generates not only the seemingly banal and 
clichéd aspects of the writing, the sense in which we have 'heard it all before'-for example, the wider cast of characters or Sandra's conversation with the psychiatrist at the start of the text—but also provides the necessary cultural repository out of which Quin's writing is able to signify and activate madness through the very profusion of its reference and reiteration. In The Words of Selves Denise Riley evokes Echo as the initiator of the ironic, who 'fingers strangeness simply through listening to what [the narrative] hears being reiterated' and in this, remains poised 'between dullness and provocation', petrifaction and newness. ${ }^{36}$ For irony to grip, she claims, it is unease as well as boredom that alerts us to the fact that something sounds as if it is in the wrong register. And Quin's text knows this; as I have discussed, the writing is punctuated by phrases that are funny and knowingly clichéd at the same time as creating an oppressive and uneasy effect. In this way, in Unmapped, the boredom that registers linguistic degradation also transforms the words into something vital and active, for 'reiteration produces more than inert copies', 37

So, ironically, it may in part be the very boredom created by the excess of repetition and stereotype in Unmapped, the fact that it comes after and knows other writing about madness, which enables it to move beyond description (or explanation) and towards expression or activation. To my mind, the glossomania of the reiterating and over-determined forms and qualities of Quin's writing elsewhere - its lack of space and lacuna — finds its most convincing expression here: my reading agrees with Giles Gordon, 'it could have been her most considerable work. ${ }^{38}$ Although the text figures the failure to articulate madness, it is also precisely the seeming exteriority of the rippling echoes of intertexts — both of others' and Quin's own — that make this writing so strange. Thus, like Felman, Unmapped insists on madness as a literary thing. In this, Quin's text is an example of 'literature's particular way of speaking' madness, which consists in its unsettling the boundary 
'between psychosis and stereotype. ${ }^{39}$ This brings madness into a state of coming out in the language: it 'is not the origin of [the] writing, the cause of meaning, but an effect' of the excessive repetition, echo and strange performance. ${ }^{40}$ In this way, I suggest, Quin's unstable, ironic and uncontainable proliferation of echoes in Unmapped works to evoke 'madness inside of thought,' inside of writing, in such a way that it might begin to activate or voice a form, performance or experience of madness at the level of language itself. ${ }^{41}$ 
${ }^{1}$ The first chapter of Quin's The Unmapped Country was previously published in Beyond the Words: Eleven Writers in Search of a New Fiction, (Ed.) Giles Gordon (Hutchinson and Co: London, 1975) and the second in Matrix 6 (London: City Literary Institute, October 1974). The Unmapped Country: Stories and Fragments (Ed.) Jennifer Hodgson (And Other Stories: London, 2018) brings the two chapters together for the first time in published form. This latter is the version of the text discussed in this article. The title is subsequently shortened to Unmapped and page numbers are in parenthesis in the body of the text.

${ }^{2}$ Daniel Deronda is given as the inspiration for The Unmapped Country in Matrix 6, p.15.

${ }^{3}$ George Eliot, Daniel Deronda (Oxford: Oxford University Press, 1984), p.235.

${ }^{4}$ Colin MacCabe, James Joyce and the Revolution of the Word (London and Basingstoke: The MacMillan Press, 1979), p.24.

${ }^{5}$ I employ the term 'madness' as it is the one Quin herself uses in Unmapped. It is also, as Charley Baker, Paul Crawford, B.J. Brown, Maurice Lipsedge and Roland Carter point out, the term which best includes and represents the social, personal, and cultural contexts that surround it in Quin's era; Madness in Post-1945 British and American Fiction (Hampshire and New York: Palgrave Macmillan, 2012), p.3.

${ }^{6}$ Shoshana Felman, Writing and Madness, (Trans.) Shoshana Felman, Martha Noel Evans and Brian Massumi (Palo Alto, California: Stanford University Press, 2003), p.41.

${ }^{7}$ Felman, p.36.

${ }^{8}$ Elaine Showalter, The Female Malady: Women, Madness and English Culture, 1830-1980 (London: Virago, 1987), p.211.

${ }^{9}$ Similar debates abound in wider critical discussion of madness: for example, Jacques Derrida's critique of Foucault's attachment to the 'concept of madness as unreason'; Writing and Difference, (Trans.) Alan Bass (London: Routledge, 1995), p.38. Louis Sass refutes the 'ubiquitous image of madness as irrationality' arguing instead for an interpretation of madness (and specifically schizophrenia) as reason in extremis; Madness and Modernism: Insanity in the Light of Modern Art, Literature, and Thought (London and Cambridge, Massachusetts: Harvard University Press, 1994), p.2.

${ }^{10}$ In 1960 Erving Goffman called the asylum a place in which the person's self 'is systematically, if often unintentionally, mortified,' Asylums (Middlesex: Penguin, 1970), p.24.

${ }^{11}$ D. A. Miller, The Novel and the Police (Berkeley, Los Angeles and London: University of California Press, 1988), p.23.

${ }^{12}$ Derrida, Writing and Difference, p.43.

${ }^{13}$ The poignancy of this description of the limits of articulation inspired the title of Beyond the Words: indeed, it was initially going to be called 'Between the Words.' 
${ }^{14}$ Gilles Deleuze describes the violent effects of madness on language as 'less a question of recovering meaning than of destroying the word,' The Logic of Sense, (Trans.) Mark Lester (London: The Althone Press, 1990), p.88.

${ }^{15}$ Derrida, Memoirs of the Blind: the Self-Portrait and Other Ruins, (Trans.) Pascale-Anne Brault and Michael Naas (Chicago and London: The University of Chicago Press, 1993), p.32.

${ }^{16}$ Felman, p.252, my italics.

${ }^{17}$ Ibid, p.14.

${ }^{18}$ See R.D. Laing's The Politics of Experience and The Bird of Paradise (Middlesex: Penguin, 1967).

${ }^{19}$ Barnes' experience is narrated by Mary Barnes and Joseph Berke in Mary Barnes: Two Accounts of a Journey through Madness (London: MacGibbon and Kee, 1971).

${ }^{20}$ John Hall, 'The Mighty Quin,' The Guardian (29th April 1972), p.8.

${ }^{21} \mathrm{lbid}$.

${ }^{22}$ Victor Sage, 'The Greater Tragedy Imposed on the Small: Art, Anachrony and the perils of Bohemia in Rebecca West's The Fountain Overflows,' Marina MacKay and Lyndsey Stonebridge (Eds.), British Fiction After Modernism (Hampshire and New York: Palgrave MacMillan, 2007), p.169.

${ }^{23}$ John Wilkinson identifies this kind of slippage - his examples are 'jewelry [sic] and jewry/Boers and De Beers - as an example of automization, where the appearance of the word itself becomes the focus, 'Too-Close Reading,' The Lyric Touch: Essays on the Poetry of Excess (Cambridge: Salt, 2007), p.159. Automization is one of the types of 'schizophrenic' language that Wilkinson takes from Sass, Madness and Modernism, pp.178-180.

${ }^{24}$ Felman, p.252.

${ }^{25} \mathrm{Ibid}$, p.82.

${ }^{26} \mathrm{Ibid}$, p.80.

${ }^{27}$ For an extended discussion of the nausea, alienation, sense of meaningless created by glossomania and excessive reiteration, see Sass, 'Languages of Inwardness,' Madness and Modernism, pp.174-209.

${ }^{28}$ Gilles Deleuze, 'He Stuttered', Essays Critical and Clinical, (Trans.) Daniel Smith and Michael Greco (London and New York: Verso, 1998).

${ }^{29}$ See Quin, Three (Chicago and Illinois: Dalkey Archive Press, 2001), p.50.

${ }^{30}$ Throughout 'The Window', Mrs Ramsay knits a 'heather-mixture stocking, with its criss-cross of steel needles at the mouth of it' for the Lighthouse keeper's little boy, Woolf, To the Lighthouse (London: Wordsworth Classics, 2002), p.19. The action stands as metaphor for the interwoven patterning of Mrs Ramsay's thoughts as well as the constructedness of the prose. The repetition of this trope in Unmapped then, not only enacts these same aspects of the metaphor but also interweaves references to Woolf, that, given Quin's close familiarity with and admiration of Woolf's work, are surely deliberate.

${ }^{31}$ Laing, Knots (New York: Random House, 1970), preface. Throughout the book Laing generates patterns of neuroses and psychoses through partial and ambivalent repetition. 
${ }^{32}$ See Quin, Passages (Chicago and Illinois: Dalkey Archive Press, 2003) p.16.

${ }^{33}$ Quin, 'Ghostworm,' The Unmapped Country: Stories and Fragments, p.127. Also published in TAK TAK TAK NUMBER 6 (London, 1993).

34 'A sparrow perched on the railing opposite chirped Septimus, Septimus, four or five times over and went on, drawing its notes out, to sing freshly and piercingly in Greek words how there is no crime and, joined by another sparrow, they sang in voices prolonged and piercing in Greek words,' Woolf, Mrs Dalloway (London: Penguin, 2000), p.26. As the notes to the text confirm, Woolf herself had 'imagined she heard the birds singing in Greek,' p.218.

${ }^{35}$ Felman, p.67.

${ }^{36}$ Denise Riley, The Words of Selves: Identification, Solidarity, Irony (Stanford: Stanford University Press, 2000), p.157.

${ }^{37}$ Riley, p.159.

${ }^{38}$ Gordon, Beyond the Words, p.11.

${ }^{39}$ Felman, p.253

${ }^{40} \mathrm{Ibid}$, p.98.

${ }^{41}$ Ibid, p.48. 